\title{
1. Public choice and the Virginia tradition of political economy
}

In the nineteenth century, what is known as economics today was known as political economy. The replacement of political economy with economics was never universal, as political economy continues to be a recognizable term and with Dimitris Milonakis and Ben Fine (2009) exploring how political economy underwent transformation into economics. As used presently, "political economy" denotes a relationship between polities and economies conceived as separate entities or realms of action. In contrast, this book treats polities and economies as entangled, which means that prudent political action cannot be determined independently of the interests of relevant economic actors, nor can prudent commercial action be determined independently of the interests of relevant political actors. Recognition of the entangled quality of political economy points toward several points of difference with common theories of political economy.

There is something unavoidably arbitrary about locating the origin of any scheme of thought. A thinker's thought always takes place against a background of preceding thought, even if it also entails a projection of a thinker's imagination into new analytical territory. While today's thought might have some original aspects, it will also bear the imprint of preceding thought that can reasonably be described as precursory to the present thought (Lovejoy 1936). Despite this unavoidable arbitrariness, it is often informative for readers to know something about the most significant precursors of a particular scheme of thought, to locate that scheme within the broader Commons of the Mind (Baier 1997) in which all thought occurs. As Melvin Reder (1999) explains, economics is a controversial and contested discipline that features several schools of thought with distinct orientations.

Public choice is one style of political economy, and is widely described as the application of economic reasoning to politics. ${ }^{1}$ This definition has informative value because it tells the reader that the text will use an economic-sounding vocabulary to discuss material that sounds like politics. Yet this definition is also ambiguous because it says nothing about what type of economic theory will be applied to politics. Different types of economic theory will lead to different types of theories of public 
choice and political economy, as Martin Staniland (1985) exemplifies in his discussion of various approaches to political economy. For instance, one prominent approach to economics holds that a sound economic theory should be based on the twin presumptions that people maximize given utility functions and that markets are in equilibrium (Reder 1982). Many economists deny one or both of those presumptions, which leads to other styles of economic theory that in turn lead to different treatments of political economy and public choice.

This book treats public choice and political economy from within an analytical framework of systems theory and entangled political economy. It does so by treating politics as a practical activity that is cousin to the commercial and industrial activity that is usually thought to be the domain of economic analysis. The scheme of thought that I advance here falls within the spirit of what has been called Virginia political economy, which originated in the late 1950s at the University of Virginia through the efforts of such scholarly notables as James Buchanan, Ronald Coase, Warren Nutter, Gordon Tullock, and Leland Yeager. Individual theorists rarely if ever assign themselves to a school of thought, for they mostly think of themselves as each forming their own tradition. A school of thought is a construction someone applies to a group of scholars to facilitate the making of points about a particular body of scholarship. Sometimes the points made are negative, with the designation of a school serving to concentrate the negative energy on a particular set of scholars and ideas. Virginia political economy became a recognizable term in this manner.

As David Levy and Sandra Peart (2013) document, around 1961 or 1962 the central administration of the University of Virginia hired a consultant to prepare a report to give the administration leverage to undermine the program that had been under construction in Charlottesville since 1956. That report opened by stating that:

It is generally recognized that at the top professorial levels this Department is staffed by unquestionably capable men and that it enjoys a considerable repute in the profession. On the other hand, the Committee has received considerable adverse criticism of this Department by reason of its close association with a particular viewpoint; and we have been given to understand that the repute enjoyed is regarded by the vast majority of economists as of a distinctly unfavorable character. It does not need to be emphasized here that the Economics Department has associated itself firmly with an outlook now known as that of the "Virginia school."

In identifying a distinctive Virginia approach to political economy, that report helped to marshal the administrative force required to destroy the program in Charlottesville, though part of that program resurfaced 
in Blacksburg at Virginia Polytechnic Institute under the rubric public choice.

The tradition of Virginia political economy can be identified, as can any scholarly tradition, in terms of a hard core of ideas from which various lines of thought are fashioned, and which both Boettke and Marciano (2015) and Wagner (2015a) explore from different but complementary angles. Virginia political economy can also be identified with two precursory streams of thought, keeping in mind the unavoidably arbitrary elements involved in any effort to identify precursors, especially when referring to a group of scholars. One stream is the classical tradition of liberal political economy whose origin is typically associated with Adam Smith, though Smith did not originate many of the ideas typically associated with him. The central idea of that tradition of political economy is that societies can generate generally orderly patterns of economic activity even though people are mostly free to direct their lives as they choose. This classical liberal vision of political economy sought to explain how a society grounded in a strong presumption for individual liberty and responsibility for one's self-governance can operate in an orderly manner with but modest political participation in economic activity. To be sure, Virginia political economy arose during the height of the neoclassical period in economic theory, and could easily be misidentified with the neoclassical tradition. But misidentification it would be, for the central theoretical claim of neoclassical economics was the formal identity of liberalism and collectivism as systems of economic order, as Baumol (1965) and Dobb (1969), among others, convey. This formal identity reflected recognition that the first-order conditions for an optimal allocation of resources were the same under capitalism and socialism. This identity of liberalism and collectivism was not a claim that would have been advanced within the classical tradition, nor was it a claim that appeared sensible within the tradition of Virginia political economy, for reasons Milton Friedman (1953a: 277-319) identified in his reviews of separate books by the socialist writers Oskar Lange and Abba Lerner, where Friedman contrasts a focus on the technical identity of necessary conditions with a focus on the different operating properties of alternative institutional arrangements for the governance of human interactions.

The second stream of precursory thought was the Italian tradition in public finance that arose in the 1880s and which had mostly disappeared by the late 1930s, which Buchanan (1960) and Fausto (2003) survey, and with McLure (2007) surveying the Paretian-inspired orientation toward this analytical material. Prior to the appearance of this tradition, as well as after its disappearance, public finance was largely construed by its theorists as an exercise in elaborating maxims for applied statecraft. 
Most scholars of public finance have sought to offer advice or maxims for rulers about how to advance the public good in some fashion as this was articulated by the expositors of those theories. Hence, public finance addressed such questions as how large public budgets should be, how progressive taxes should be, and how should tax revenues be distributed among items of possible public expenditure. In contrast, the Italian tradition arose as an effort to incorporate political activity into the explanatory framework of economic theory. Within this tradition, political processes reflected the same logic of economizing action as did market processes, with differences between the processes arising because of differences in the institutional environments that governed interactions among participants. Indeed, in the Foreword to the German translation of Amilcare Puviani's (1903) Teoria della illusion finanziaria [Theory of fiscal illusion], Gunter Schmölders (1960) explained that:

over the last century Italian public finance has had an essentially political science character. The political character of fiscal activity stands always in the foreground .... This work is a typical product of Italian public finance, especially a typical product at the end of the nineteenth century. Above all, it is the science of public finance combined with fiscal politics, in many cases giving a good fit with reality [my translation].

Antonio de Viti de Marco is particularly notable with respect to the Italian tradition of public finance, with Manuela Mosca (2011) presenting an informative treatment of De Viti's character and work and with Giuseppe Eusepi and Richard Wagner (2013) locating De Viti as a significant precursor to public choice theory. De Viti's working life pretty much shadowed the life of the classical period of Italian public finance. In 1888, De Viti published Il carattere teorico dell'economia finanziaria [The theoretical character of public finance]. This small book was expanded three further times during De Viti's lifetime, culminating finally in the 1934 publication of Principii di economia finanziaria [First principles of public finance]. This book was translated into English (De Viti 1936), and is the only booklength statement of the classical Italian orientation toward public finance available in English. In the Preface, De Viti explains that "I treat public finance as a theoretical science, assigning to it the task of explaining the phenomena of public finance in their historical setting" (De Viti's italics).

The scholars associated with the Virginia tradition of political economy sought to develop a unified approach to political and economic activity within society by bringing forward and combining insights from the British classical and Italian traditions. ${ }^{2}$ By the late 1950s, both of those traditions had pretty much disappeared from scholarly radar screens. The classical tradition of liberal political economy had given way to the 
neoclassical tradition that was wide open to collectivist economic theories and Progressivist political programs. Public finance, moreover, was dominated by the hortatory imperative to offer Progressivist-inspired accounts of how state power could be deployed to improve society in light of widespread presumptions that market failures would otherwise plague societies.

The schemes of thought associated with any scholarly tradition that is a progressive research program can be likened to a river to which numerous scholars contribute. With multiple schemes of thought and research programs being in play at any moment, it is not unusual to find admixtures among schemes sometimes occurring due to strategic and competitive elements entailed in the generation of scholarship (Collins 1998). As the Virginia tradition developed over the half-century following publication of The Calculus of Consent (Buchanan and Tullock 1962), the mainline currents of its thought became mixed with currents from the mainstream of economic thought (invoking Peter Boettke's (2007) distinction between the mainline and mainstream branches of economic theory). This chapter seeks to filter those distinct currents to grasp the essence of public choice within the tradition of Virginia political economy (Wagner 2004, 2013, 2015a,b). To do this, some excursion into the history of economic thought is necessary, and with this excursion followed by consideration of the tangled relationship among politics, economics, and property rights that will inform the rest of the book.

\section{PAST ECONOMICS AS ECONOMICS OF THE EXTENDED PRESENT}

Economists are notorious for having disdain for old books. Few doctoral programs offer fields in the history of economic analysis and many of them don't even offer courses on the topic. Many reading lists for economics courses feature few items more than five years old, and many of the featured items have yet to be published. The image created by such reading lists is that past scholarship has little to offer present scholars. This image reflects what appears to be the widely held presumption that whatever was once valuable in the past has already been incorporated into present economic theory, so avoiding old books avoids wasting time in exploring blind alleys, which in turn makes economic theory more progressive than it would otherwise be. We can honor the past by recognizing that we are standing on the shoulders of giants, but there is no need to read the contributions of those giants because those of their formulations that are still useful are already incorporated into current theory.

This widely held belief is just that, a belief or an article of faith. It has 
neither evidence nor theory in its support. Indeed, as theory it entails a thoroughgoing embrace of the theory of perfect competition applied to the generation of economic scholarship, along with the claim that perfect competition pertains to that generation in each and every instant of time. Yet very few economists believe that the theory of perfect competition gives a good description of actual economic processes or arrangements. Furthermore, that belief runs afoul of the micro-theoretic basis of the constitution of economic theories, as Arthur Lovejoy (1936: 3-23) explains in the first of his William James Lectures titled "The Study of the History of Ideas." An economic theory is packaged as a macro-theoretic entity. That entity, however, is constituted as a string of micro-theoretic entities. Consider the use by some theorists to explain involuntary unemployment as a consequence of the need for firms to pay efficiency wages above the competitive level of wages. While this idea is packaged as a macro entity, or what Lovejoy described as a "unit-idea," it is actually constituted through stringing together a number of micro bits of theory. Among those bits are assumptions about business firms, agency theory, compensation schemes, marginal productivity theory and its alternatives, and the meaning of competition, among other bits, all of which can be combined in various ways.

The construction of an economic theory is thus an exercise in combinatorial arithmetic. A deck of cards can provide a simple illustration of the complexity that arises quickly from this type of arithmetic. There are some 635 billion ways that a sequence of 13 cards can be drawn from a deck of 52 cards. Keeping with this illustration, suppose a theory of involuntary unemployment of the efficiency wage variety requires a sequence of 13 micro bits to be strung together from among 52 bits that are available. If so, there are some 635 billion ways a theory of efficiency wages can be articulated. Furthermore, suppose it takes a speedy theorist one day to organize and articulate one such theory. If a thousand scholars are involved in constructing efficiency wage theories, it will take 635 million days to articulate all such theories, or around two million years. It is surely implausible and even unreasonable to claim logical support for thinking that present theory inexorably incorporates the best from the past. To be sure, one could recur to argument about statistical sampling to assert that full enumeration would be wasteful. Even a sample size of one percent, however, would require 20,000 years to allow an inference reasonably to be made by standard statistical procedures. Claims on behalf of the proposition that competition among theorists generates some objective notion of Truth are undecidable, as Chaitin et al. (2012) explain in their exploration of the world of undecidability that arises in pursuing Kurt Gödel's insights about the unavoidably arbitrary character of any closed scheme of thought. 
Kenneth Boulding (1971) asked: "After Samuelson, who needs Adam Smith?" Boulding's effective answer was "everyone," and he justified his response by locating Smith within what he called the "extended present." Boulding's poetic prose and my combinatorial arithmetic lead to the same recognition that past scholarly contributions and formulations can often provide valuable insight for current theoretical efforts. There is no guarantee that what is carried forward from past to present will prove to be the most useful of all the possibilities. Someone in 1876 looking back to 1776 might select some things for usefulness and discard others. Yet someone in 1976 looking back to 1776 might make a different selection due to any number of things: the questions to be addressed by current theories might have changed; alternatively, new methods of analysis might have been created that brought tractability to formerly intractable ideas. Adam Smith's use of the diamond-water paradox was kept alive for the better part of a century before being abandoned. Adam Smith's interest in increasing returns was set aside in favor of the tractability of constant returns, only to be revived two centuries later when new schemes of thought made it possible to work with those ideas, as Paul Romer (1986) set forth and with Buchanan and Yoon (1994) collecting a set of essays on increasing returns.

Nicholas Vriend (2002) illustrated nicely Boulding's theme about the extended present when he asked: "Is Hayek an ace?" By "ace," Vriend meant an economist who worked with agent-based computational models. As a literal matter, there is no way Hayek could have been an ace because those techniques weren't around when Hayek $(1937,1945)$ argued that the central problem of economic theory is to explain how coherent macro patterns can emerge in societies when no micro entity knows but a pittance of the knowledge that would be needed actually to construct that pattern. In doing this, Hayek was, among other things, denying the meaningfulness and usefulness of standard theories of perfect competition as based on postulated conditions of full awareness of relevant knowledge. The analytical challenge for Hayek was to explain how orderly patterns could emerge in the face of limited and divided knowledge. This challenge could never be met by postulating equilibrium and supporting that postulation with econometrics because doing that gave no insight into the actual workings of the social world. Hence, Vriend argued that Hayek most surely would have been an ace had those schemes of thought been available when he was wrestling with his ideas about divided and distributed knowledge. Someone who can now work with agent-based computational models can find illuminating formulations in Hayek, and formulations that are much more open to agent-based techniques than the subsequent equilibrium-centered presumptions that such economists as Grossman and Stiglitz $(1976,1980)$ work with, though it should also be recognized that agent-based modeling 
also unavoidably butts against the same problems of unavoidable incompleteness, as Stephen DeCanio (2014) examines in exploring the limits of genuine knowledge about economy and society.

\section{THE MISGUIDED DISTINCTION BETWEEN CLASSICAL AND NEOCLASSICAL ECONOMICS}

In textbooks on the history of economics, students learn that the principal dividing line in the history of economics is that which separates the classical from the neoclassical tradition. This separation reflects differences in how economists go about explaining differences in prices. Within the classical tradition, prices were explained as differing because of differences in the cost of producing different products. If it took twice as much time to catch a deer as it did to catch a beaver, the price of a deer would be twice the price of a beaver. This cost-of-production theory of value led the classical economists to ponder such observations as the price of diamonds being vastly higher than the price of water, even though people can live without diamonds but can't live without water. To be sure, not all economists from the eighteenth century pondered this matter. Adam Smith and his British successors did. But Richard Cantillon and the physiocrats in France did not. Even more, the Spanish Jesuits associated with the University of Salamanca centuries earlier (Marjorie Grice-Hutchison 1978) did not do this. Those Jesuits, moreover, had developed a theory of the self-organizing features of economic activity within society well in advance of the contributions of the Scottish Enlightenment to this effect. Indeed, Simon Bilo and Richard Wagner (2015) speculate that it is conceivable had some historical events surrounding the discovery of gold on the American continent turned out differently, we would now attribute the idea of societal self-ordering to the Spanish Enlightenment rather than the Scottish Enlightenment.

Still, the diamond-water paradox plagued the British liberal tradition running from Adam Smith to John Stuart Mill. This paradox was resolved finally by the advent of the marginal revolution late in the nineteenth century, with economic theory thereafter described as neoclassical economics, to recur to the difference in how economists accounted for differences among prices. Prices were now explained with reference to the marginal utilities of different items. Gone were explanations grounded in costs of production. With this shift in the explanation of price, the diamond-water paradox dissolved. Without doubt, having water to drink is more significant for human life than having diamonds to wear. This comparison, however, is irrelevant for explaining prices. What matters 
for doing that in the neoclassical tradition are the relative values of small increments of different items. Water is plentiful relative to the desire people have for it, so its price is low. Diamonds are scarce relative to the desire people have for them, so people are willing to pay high prices for a few more diamonds while paying very little for a little more water.

It is often observed that winners write history. This observation pertains to the writing of the history of economics. Locating the central dividing line in the history of economics as based on different explanations for prices reflects the central orientation of neoclassical economics as primarily a theory of prices and resource allocations. This neoclassical view of the object of economic theory is conveyed often in textbook references to the primary functions of an economic system as being to determine what is to be produced, how it is to be produced, and how that production is to be distributed. ${ }^{3}$ While it is necessarily the case that any system of economic interaction can be described in terms of providing answers to such questions, this does not mean that these questions provide a direct focal point for economic analysis. Theories have both foregrounds and backgrounds, and these can be reversed between different sets of theories.

The neoclassical scheme of thought mostly treated resource allocations as the immediate objects of theoretical examination. Adam Smith, David Ricardo, and John Stuart Mill all operated with cost-of-production theories of value, and so would be lumped together as members of the same tradition within a neoclassical construction of the history of economics. Likewise, William Stanley Jevons, Carl Menger, and Léon Walras all operated with a marginal utility explanation of prices, and so likewise are lumped together within the same scheme of economic theory, though William Jaffé (1976) emphasizes the differences among those three theorists.

Prices and allocations are not, however, the only possible objects on which an economic theory can focus. For neoclassical economics, prices and allocations occupy the theoretical foreground. The background is occupied by various institutional arrangements that are thought necessary for economic activity but which nonetheless are thought to be of secondary analytical interest. Within the spirit of much classical economics, however, it was institutional arrangements that comprised the foreground, with resource allocations relegated to the background, as Nathan Rosenberg (1960) explains in his examination of how it was institutions more than allocations that were central to Adam Smith's conception of economic theory. Economics within the classical motif was principally concerned with the governance of human interactions and their consequences: resource allocations were products of human interaction but were not direct products of human choice. 
An alternative scheme for organizing the history of economics would locate the prime differences in the accounts different economists give for the observed orderliness of societies. An alternative genealogy of the history of economics could be advanced based on differences in the objects of economic inquiry. One line of economic theorists would run in terms of economists who thought the prime object of economic analysis was relative prices and resource allocations. This line of classification would place David Ricardo and Léon Walras in the same analytical camp because both were centrally concerned to explain prices and allocations. Sure, Ricardo and Walras took different approaches to explaining relative prices; however, both reflected agreement that the explanation of relative prices and resource allocations was the central object for economic analysis.

This alternative scheme for classification would likewise place Adam Smith and Carl Menger in the same analytical camp despite their taking different approaches to the explanation of price and value. Most significantly in this respect, neither of these economists was centrally concerned with prices and allocations. Among other things, they recognized that resources could not allocate themselves but rather were allocated by people in consequence of their interacting with other people inside some institutional framework that governed and structured those interactions. Economics within the Smith-Menger line of analysis was centered on the institutions of human governance.

Looking ahead, Virginia political economy as it emerged in the late 1950s fell clearly within this Smith-Menger scheme of analysis. That scheme of analysis, however, was often misidentified as a libertarian strain of neoclassical analysis, recalling that the first-order conditions for economic efficiency within the neoclassical scheme are identical for liberal and collectivist economies because allocative efficiency is defined independently of any kind of institutional arrangement that governs interaction among people. This misidentification is a product of adopting the neoclassical writing of the history of economics. It is interesting to note in this respect that Virginia political economy has often been identified as a variant of Chicago-style economics in light of high esteem accorded to Frank Knight by so many Virginia faculty members. And yet James Buchanan, undoubtedly the premier figure in the history of Virginia political economy, expressly rejected his Chicago teachings in noting early on that he wanted to construct an entirely different approach to public finance than what he learned at Chicago, as Marianne Johnson (2014) explains in her examination of James Buchanan's early work on the theory of public finance. 


\section{PLAUSIBLE VS. DEMONSTRATIVE REASONING IN POLITICAL ECONOMY}

Classical economics was grounded on plausible reasoning; neoclassical economics largely embraced demonstrative reasoning. While the natural home for the public choice motif of Virginia political economy lay in the plausible reasoning of classical economics, it arose in the heyday of demonstrative reasoning, so its formulations often used that scheme of thought, leading in turn to misidentification of its analytical hard core. The classical scheme of liberal economics starts with recognition that economic activity entails regularities that call for scientific articulation. The conceptualization of markets and of a market economy took shape as this inquiry into social theory proceeded. The purpose of such inquiry was to explain how generally orderly patterns of activity emerge within societies even though there was no person or office in society who constructed that regularity. The economic theory of a market economy bore a close relationship to the political philosophy of liberalism. The economic theory explained how socially orderly patterns of activity emerged even though individuals were free to choose how to deploy their talents; the political philosophy explained that socially beneficial properties emerged out of individual interaction within the liberal order of society.

The origins of economics as a subject of scientific inquiry lay in recognition that social life presented regular patterns that called for explanation. It was apparent that the prices and quantities of the products exchanged through market transactions were not determined by some person or bureau. While there were plenty of positions of authority within societies in those days, there was also a good deal of scope for people to transact on terms of their choosing. The economic regularities that people observed occurred on both large and small scales. On a large scale, an influx of gold from the newly discovered American continent was followed by a general rise in prices throughout the gamut of market transactions. On a small scale, it was often noticed that such an event as a public mourning that followed some royal death was accompanied by a rise in the price of black cloth.

The classically liberal theory of a free-market economy emerged as the product of interested scholars trying to give a coherent account of such observations. What was especially significant about these theorists is that they were engaged in plausible reasoning, in contrast to the focus on demonstrative reasoning that came into play late in the nineteenth century (Polya 1954). Plausible reasoning is empirical; demonstrative reasoning is logical. This isn't to say that plausible reasoning is non-logical or illogical, for logic is central to plausible reasoning. Plausible reasoning starts from 
recognition that the object of inquiry cannot be known in full detail to the inquirer. Similar to the position of the blind men from Hindustan, each of whom felt a piece of an elephant but none of whom felt the full elephant, plausible reasoning seeks to develop plausible analyses based on knowledge that is inescapably limited and incomplete.

The liberal economists recognized that regularities pervaded the economic activities of societies, and sought to give coherent accounts of those regularities. The thrust of these invisible-hand types of explanations was to explain that outcomes that often were socially beneficial emerged out of individual activities that mostly were narrowly focused on local concerns and interests and not on some societal or global object of concern. In this setting, a market economy was the term used to describe social arrangements where transactions occurred within an institutional setting dominated by rights of private property and liberty of contract. People could dispose of or acquire property through transactions and in terms that were agreeable to the affected parties. Such transactions were obviously beneficial to the parties or else they would not have agreed to the transactions. To be sure, there could be cases when transactions occurred under duress, as when someone whose wheel came off a wagon in a remote spot accepted help from a passerby at an exorbitant price because of the coming darkness combined with a strong fear of the beasts that might come out of the forest at night. There could also be cases where the buyer accepted the seller's testimony that a mare was fertile only to find later that she had been spayed.

There was, in other words, no presumption that all transactions were mutually beneficial, but only that mutual benefit was the norm of voluntary exchange. In cases of duress and fraud, moreover, there were legal remedies that disgruntled buyers could pursue. These legal options for remedy were likewise addressed within the framework of plausible reasoning. For neither market transactions nor legal actions was there any claim about global perfection, for this awaited the shift of attention from plausible to demonstrable reasoning that came late in the nineteenth century.

Late in the nineteenth century the neoclassical movement in economic theory started. So too did the growth of socialist movements and welfare states in Europe, followed by the emergence of Progressivism in the United States in the early twentieth century. Progressivism called for the replacement of complex systems of governance based on separated and divided powers with a strong administrative state with the reins of power held by right-minded people. Woodrow Wilson's (1885) call for administrative centralization set the analytical stage for theorists to support monocentric over polycentric arrangements of political offices. It was nearly a century later when Vincent Ostrom (1973) set forth a cogent articulation of the 
polycentric alternative that informed the original constitutional arrangement. This shift in economic theory and political context was accompanied by a shift from plausible to demonstrative reasoning. Within the spirit of plausible reasoning, liberal economists sought nothing more than to explain how a society of largely self-governing individuals could generate coherent patterns of economic activity that were generally recognized as being beneficial. The plausible nature of such reasoning meant that differences of opinion were always in play within a general presumption in favor of self-ordered liberal governance, as Lionel Robbins (1952) and Warren Samuels (1966) explain in their examinations of the classical orientation toward political economy.

This default setting in favor of self-governance changed as neoclassical economics took shape, not so much due to marginalism per se as to the shift to demonstrative reasoning that accompanied the marginal revolution. In conjunction with this path of development, economists came increasingly to articulate claims about market failure. These claims were articulated against a background of a theory of perfect competition, the assumptions of which were rarely to be found in economic life. In the wake of the advance of market failure theories, welfare economics developed into the systematic study of governmental intervention into the marketgenerated economic organization of societies, classic illustrations of which are James Meade (1952) and Francis Bator (1958). The object of such analytical efforts was to attain demonstrative knowledge about when governmental intervention into market arrangements could represent societal improvement.

While theorists differed in the size of the domain to which market failure arguments pertained, almost invariably they worked with the analytical presumption that political agents would operate with a single-minded dedication to follow the dictates of welfare economics, if only the analysts would speak with the same voice. It is here where modern public choice analysis starts. As with most such beginnings, there is no one instant to date the start. As is almost always the case in these matters, there were precursors and forerunners. In any case, public choice came about when theorists began to treat politicians and public officials as ordinary people. Within the spirit of welfare economics, politicians and public officials were not ordinary people engaged in transactional activity. Transactions were the domain of people in business, who were carriers of the commercial syndrome (Jacobs 1992). Politicians and public officials, however, were carriers of the guardian syndrome and so shunned commerce to carry out their corrective and guardian activities as these were described by theories of welfare economics. Public choice theorists, however, recognized that politicians and public officials had little reason to shun commercial activity and 
had every reason to get involved with it, possibly creating in the process what Jacobs termed "monstrous moral hybrids."

The so-called marginal revolution in economic theory that started to take shape in the late nineteenth century overcame such logical conundrums as those expressed by the diamond-water paradox, but did so at the expense of narrowing the focus of economic analysis from the governance of systems of social interaction to the analysis of the choices of presumptively maximizing individuals within some given system of social interaction. In conjunction with this narrowing of the object of scientific inquiry came a shift in analytical motif from the earlier concern with plausible reasoning applied to open systems to a treatment of closed systems using demonstrative reasoning. Where the earlier theorists reasoned in terms of social systems that possessed tendencies toward what might be called states of equilibrium, recognizing that such states were mental constructions and not descriptions of reality, the modern or neoclassical theorists reasoned in terms of trying to demonstrate conditions under which systemic equilibrium would occur.

Prior to the advent of marginalism, competition was conceptualized as a normal activity of people who were free to choose their activities. With the advent of marginalism, however, competition came to be treated not as a verb but as an adjective where competition could vary between some notion of perfect competition and various notions of imperfect competition (McNulty 1968). Perfect competition, in turn, was defined in terms of demonstrative reasoning to be a set of conditions under which it must be the case that all items of a product sell for the same price. Absent such conditions, competition would be described as imperfect and hence subject potentially to perfection through appropriate interjections of policy. To be sure, one might wonder why a situation when all participants are price takers would be labeled a state of perfection when it implies that no new products or services are ever created. After all, one cannot be a price taker in creating a new product or service. But to think in this manner is to think in terms of plausible reasoning, and the neoclassical period was infused with the spirit of demonstrative reasoning wherein a good economic theory had to give a precise answer to a well-defined question.

What resulted was recognition that perfect competition was an impossible standard because reality was necessarily imperfect when compared against that standard. With this recognition arose the systematic study of how governments might intervene into market processes to bring about a better state of affairs as this might be judged by market participants. The standard of betterness that economists adopted was that of Pareto efficiency. Within this standard, market imperfection described a situation in which through state action it would be possible to make at least one 
person better off without making anyone worse off. Such situations were addressed in terms of demonstrative reasoning because of the implausibility of actually trying to do such a thing. From this line of analysis came recognition that there is no principled limit to the reach of state action to improve on the results of market interaction. This doesn't mean that economic analysis counseled a vast increase in the extent of state intervention into economic life. It rather means that there was no principled limit on the reach of political intervention.

The actual reach depended on a calculation of the costs and benefits of intervention. State intervention isn't free. Offices must be created and staffed, and taxes must be imposed. In some cases the potential gains from intervention might exceed the costs. As for who would make such calculations and make such judgments, it was generally left as an article of faith that existing political arrangements would generate the correct answer. Indeed, much of the modern literature on political economy has formalized just this line of analysis, as a later chapter shall examine. For now, however, it can simply be noted that the growth of the Progressivist political program where there is no principled limit on the reach of the political into society fit well with the neoclassical shift to a demonstrative style of reasoning in conjunction with the formalization of that style of reasoning into welfare economics in the middle years of the twentieth century.

\section{ON LIGHTHOUSES, PUBLIC GOODS, AND PLAUSIBLE REASONING}

Contemporary economic theory has harbored several controversies about whether particular types of services are better categorized as public or private goods, with television broadcasting (Minasian 1964) and lighthouses (Coase 1974) serving as archetypes of the points at issue. The signals emitted by television stations and lighthouses seem clearly to fit within the purview of Paul Samuelson's $(1954,1955)$ definition of a public good where a single unit of production can provide unlimited units of consumption, at least within some geographical range covered by the public good. Despite fitting within the rubric of a public good, television signals and lighthouse signals are both capable of being financed by charges paid by users of those services. Yet charging positive prices will exclude some potential users who value the service, even if they value it at less than the price. By the very definition of a public good, excluding anyone who places a positive value on the service violates the first-order conditions for Pareto efficiency. Within the framework of demonstrative reasoning, an observation that vendors can find ways to sell such public goods as television 
programming and lighthouse signals does not transform those goods into ordinary private goods.

Within the framework of demonstrative reasoning, controversy over whether something is a private or a public good is potentially interminable. There is surely no other possible situation when the classification into private and public is based on some analyst's presumption about individual states of mind regarding their valuations of what are claimed to be public goods. Within the standard Paretian conditions, an efficient level of output is defined as the level of output where the combined willingness of all those who place positive value on the service equals the cost of providing a marginal unit of that service. There is no way to tell whether or not those conditions have been met in any particular case. The willingness of someone to pay for something is revealed only at the moment someone chooses to buy something, or not to buy it. The conceptual categories of orthodox public goods theory are pieces of logic that are part of a scheme of demonstrative reasoning. Such categories can be used as logical exercises, but those exercises cannot be applied directly to reality because they would require the analyst to fill what are nothing but imaginary economic boxes (Wagner 2015b).

To work with such categories requires a scheme of thought grounded in plausible reasoning accompanied by open-ended rather than closed-form modeling. Consider Coase's (1974) treatment of lighthouses in England around the eighteenth century, a treatment that Krause (2015) amplifies by providing relevant illustrations. Those lighthouses were financed by tolls collected from ships that anchored in harbors in the vicinity of those lighthouses. It is easy to understand why proponents of market-based arrangements within society would point to lighthouses as being private and not public goods, given that they think lighthouses are better provided through market-like transactions than through a bureaucratically operated Department of Lighthouses. Such proponents, however, would surely be wrong because the services of those lighthouses are valued by some relevant public. Demonstrative reasoning, however, is incapable of identifying such valuations, for these valuations are revealed only through the actions people take within particular institutional settings.

The public goods quality of lighthouses, and many similar services, resides in the situational logic suitable for plausible reasoning. We can affirm that there is widespread public interest in having ships arrive safely at their destinations rather than crashing on rocks along their paths. That affirmation, moreover, has nothing to do with presuming to know individual marginal valuations for such services. Affirmation rather resides in recognizing that the owners of ships and those who sail on ships value the safe arrival of those ships in harbor. The same goes for the owners of the 
cargoes carried on those ships, as well as for the merchants who are scheduled to receive the merchandise carried by those ships. This very situation means that profit can be captured through finding ways to create transactions that reduce the danger ships face from crashing on rocks. Just what that might entail is a matter of entrepreneurial and organizational discovery (Kirzner 1973, 1979), of which the possibilities are numerous and open-ended prior to the emergence of particular historical configurations.

For instance, a set of ship owners might form an organization to support a network of lighthouses financed by tolls collected from member ships as they reached port. This scheme pretty much mirrors what Coase (1974) described, though Coase described a situation where a governmental agency collected the tolls. In the absence of government-supported collection, a situation could arise where some ships that arrived at port were not owned by one of the members of the organization. This situation might be sufficiently rare that the members of the organization would ignore it. Alternatively, the ship owners might acquire docking rights at the harbors protected by the lighthouses. In this case, ships would not be allowed to dock without belonging to the organization. To be sure, that organization could well develop a scheme of pricing where dues varied with the number of ships docked during some period. Regardless of how the organization's activities were provided and financed, lighthouse services would reasonably qualify as a good of interest to a relevant public, though that relevant public need not be the set of all people residing within a nation or other political unit.

The analytical boxes labeled "market failure" and "market success" are imaginary boxes that exist only within the framework of demonstrative reasoning (Wagner 2015b). In contrast, plausible reasoning pertains to situations where people perceive situations that render them uneasy and which in turn induces a search for means to reduce that uneasiness. The analytical foreground is thus populated by people seeking to fashion institutional arrangements that allow them to overcome particular sources of uneasiness. Public goods theory in its demonstrative mode presents a caricature of the actual historical possibilities open at any particular moment. Which possible option among a menu of possibilities might be put in play at that moment will be generated through interaction among interested parties within that particular societal setting.

\section{INTERPRETING OLD TEXTS AFTER HALF A CENTURY: THE CALCULUS OF CONSENT}

James Buchanan and Gordon Tullock's (1962) The Calculus of Consent is undoubtedly the Ur-text of Virginia political economy, as Wagner (2013) 
notes. Yet several forms of political economy are in play, and with those forms pointing in different analytical directions. In recognition of this situation, Blankart and Koester (2006) distinguished between public choice and political economics as alternative forms of political economy. Yet the opening line of the Preface to The Calculus of Consent reads: "This is a book about the political organization of a society of free men" (italics in original). It's clear that there are different ways of bringing economic theory to bear on politics just as there are different ways of constructing economic theories. Any such act of construction will start with some preanalytical cognitive vision (Schumpeter 1954: 41) which the scholar then seeks to articulate so as to make it intelligible to others. The articulation of that vision will occur through some ordered string of units of thought. How that thought is strung together and how those units are conceptualized will depend on the tools of thought that an author has available to work with. Vriend (2002) explains that agent-based computational modeling offers a solid platform for working with some of Hayek's ideas about knowledge that is fragmented and distributed and nowhere possessed by one person or office. Yet such tools of thought weren't available to Hayek, so he had to resort to literary reasoning that was easily reducible to a statement of equilibrium conditions, the incoherence of which was subsequently set forth by Grossman and Stiglitz $(1976,1980)$. In doing this, however, Grossman and Stiglitz did not dispute Hayek but ignored him. The ability to articulate a pre-analytical cognitive vision depends on the tools of thought that are available to an author.

The interpretation of The Calculus of Consent and its significance for Virginia political economy and public choice is likewise influenced by tools of thought. Ideas about complex systems and agent-based computational modeling were not available to Buchanan and Tullock, though some game-theoretic models were then available. What resulted was an effort at articulation that had a mixed-metaphor quality about it that is subject to misinterpretation, as Wagner (2013) explains. The Calculus of Consent was conceived as an effort to explain that the complex constitutional arrangement that was founded in 1789 reflected a coherent economic logic of governance through divided and separated powers. Indeed, Vincent Ostrom's (1987) Political Theory of a Compound Republic, first published in 1971, is effectively a flying buttress to The Calculus of Consent. Where Buchanan and Tullock took recourse to some of the simple equilibrium models that were then used by economists to illustrate some of their arguments, Ostrom maintained contact with the complex constitutional arrangements that were established in 1789 .

The constitutional scheme of separated and divided powers meant that the median voter model was more a fictional construction than a 
reasonable model of a constitutional arrangement. A median voter model might pertain for a five-member town council that has the sole authority to allocate tax revenues among expenditure items. It would not, however, apply to complex arrangements of separated and divided powers where concurrence among different entities is required before collective action can be undertaken. In these kinds of settings, outcomes are products of interaction and negotiation and not products of choice. The American constitutional system created a complex structure of divided and separated powers that required concurrence among different sets of people. Within a bicameral legislature, for instance, the degree of concurrence that is required varies with the principles by which the two chambers are selected. Within the original constitutional setting, the federal Senate was selected by state legislators while the House was selected directly through election. In consequence of constitutional amendment in 1913, the federal Senate also became selected directly through election. This change surely created more commonality among the electorate than had previously existed (Bueno de Mesquita et al. 2003). In a two-chamber system where both chambers are staffed through at-large elections, selection is likely to operate similarly in both chambers. Quite different properties would result should one chamber be populated by property owners and the other by renters, and with legislation requiring concurrence between both chambers. In this respect, one well cited game-theoretic exposition of fair division occurs where one person slices a cake and the other person takes the first slice. This formulation is similar to requiring concurrence between differently constituted chambers.

In any case, the prime purpose of The Calculus of Consent was to explain the complex system of government that the American Constitution established and which had been under strenuous attack by Progressives at least since when Woodrow Wilson (1885) wrote Congressional Government, where he extolled the virtues of a strong administrative apparatus in place of continual congressional negotiation and logrolling. The Calculus of Consent was conveyed mostly by equilibrium formulations of a relatively simple sort, even though the purpose of the book was to explain how the complex American constitutional system made sense from the perspective of economic logic and even though that sense would vanish if the system were actually reduced to conform to the simplicity of the logic, as Vincent Ostrom $(1973,1987,1997)$ recognized with especial cogency. 


\section{SIMPLE VOTING RULES AND COMPLEX SYSTEMS OF GOVERNANCE}

The central theme of The Calculus of Consent has often been reduced to support for a qualified majority voting rule over simple majority voting. The Calculus of Consent does present a theory of constitutional choice in terms of a selection of a voting rule for undertaking collective action, and with that choice illustrated in terms of a representative agent who appraises a tradeoff between external costs and decision costs. That individual is imagined as evaluating different rules for supporting collective action by a group, and with Munger and Munger (2015) setting forth a careful analysis of various frameworks for choices by groups. The task the representative agent faces is to select the voting rule that minimizes the full costs of undertaking collective action. As the share of the group that must agree increases, the cost of reaching collective decisions rises but the cost of being victimized by collective action falls. In the limit, the external costs of being victimized by having collective action undertaken of which a representative individual disapproves disappears when unanimity is required. Yet unanimity can entail particularly high decision costs because of the delay in receipt of the benefits of collective action due to increased bargaining costs that accompany increases in the required degree of consensus.

This simple framework of constitutional choice as selection of a voting rule denies any simple identification of democracy with majority rule. Indeed, as an ideal benchmark it embraced unanimity, while also noting that this ideal was unattainable. What resulted was support for some qualified majority rule. The discussion and debate over this constitutional formulation swirled around whether the majority principle was a suitable principle for democratic governance or whether some higher degree of support was a superior principle. The reduction of constitutional choice to selection of a voting rule was analytically tractable as it could be illustrated by summing the two functions of decision costs and external costs, each expressed as the percentage of the group that must agree before it can undertake collective action.

Yet tractability also entails a tradeoff, as Wagner (2010a) explains. Tractability makes it easier to illustrate a point and to explore some implications of a model. Reducing constitutional choice to the action of a representative individual appraising a tradeoff between two functional relationships entailed in a voting rule is a simple framework that is easy to understand and free from ambiguity. Sure, it might be difficult to specify parameters for those functions, but that difficulty points to a lack of knowledge and not to ambiguity about the topic under examination. 
Everyone can agree that the topic reduces to specification of two functions even if they aren't sure about how to estimate those functions.

The obverse of securing tractability by using simple models to represent complex phenomena is to obscure what is occluded from view by that model. Instruction about this can be seen by comparing the reduction of constitutional choice to a voting rule with Knut Wicksell's (1896 [1958]) formulation of qualified majority voting along the lines that Wagner (1988) set forth. The English translation of Wicksell was of the second of three essays. Consideration of the full set of essays shows that Wicksell's formulation of the problem of constituting a system of self-governance had significant structural features that were not reducible to a voting rule. In other words, a vote would be taken, but this vote stood at the end of a process that had significant structural features, and it was those structural features that shaped just what it was that would be voted on. In short, Wicksell sought to articulate a set of institutional arrangements that would reflect a roughly consensual approach to governance, recognizing that consensus is a plausible and not a demonstrative term. Consensus, however, is not identical with unanimity, for unanimity is a demonstrative term whereas consensus is a plausible term.

One feature common to both Buchanan and Tullock and to Wicksell is the priority of liberalism over democratic or republican government. The anthropological evidence is pretty clear that humanity began in groups, as illustrated by family members being obligated for one another's debts as well as by the absence of last names in the west, as Henry Maine (1864) explained in the context of advancing his claim that the direction of institutional movement in the west had been one of relationships grounded in status giving way to relationships grounded in contract. ${ }^{4}$ To be sure, Maine was starting to see signs of a reversal of that direction of movement, and the past century of Progressivist domination has seen an acceleration of the replacement of contract with status. In any case, historically the individual was an extraction from the group. It was not a matter of individuals coming together to form a group. From this point of departure, there is a choice about how to proceed with respect to constitutional formation and analysis. One can start with all property held collectively, as illustrated by family members being responsible for one another's debts and as advocated by Murphy and Nagel (2002). This point of departure, however, is analytically incoherent, at least without sneaking hidden presumptions of private property into the analysis. To posit a collective starting point allows no action to take place unless some prior pattern of structured relationships is also posited, as illustrated by tribal chiefs or councils of elders. While such structured relationships are historically accurate, they also violate the purely collective point of departure. The tribe or family starts 
with a structured pattern of relationships out of which collective action emerges, and with that action, including action that changes the structure of those relationships, being largely consensual in nature.

The point of departure that starts with individuals and generates groups is likewise mythical. It does, however, fit with certain sentiments held widely in the west, at least until recently when they have come increasingly under challenge. The emphasis in Buchanan and Tullock (1962) reflects this liberal point of departure where the formation of a system of government is a product of people using their prior rights of property. This point of departure, moreover, was asserted in the American Declaration of Independence where it was announced that "governments derive their just powers from the consent of the governed." In their constitutional tradeoff, Buchanan and Tullock (1962) sought to use plausible reasoning to explain how people might accept some modicum of collective imposition because they thought the overall constitutional bargain would nonetheless be a good one. That treatment in terms of plausible reasoning subsequently became misunderstood as economics became dominated by demonstrative reasoning.

Wicksell (1896 [1958]) reasoned similarly, only he placed the voting rule at the culmination of a political structure that he plausibly thought would lead to outcomes that would broadly reflect consensus among the members of Swedish society. In the end, he advocated qualified majority voting within the Swedish parliament, and illustrated what he meant by referring to three-quarters and four-fifths consent to approve fiscal measures. But far more than a voting rule was involved in Wicksell's suggested constitutional framework because a vote would be the last step in a process that he thought would promote government through consensus. Wicksell's constitutional structure featured both executive and parliamentary processes, both constituted so as to work toward consensual outcomes.

With respect to parliament, Wicksell thought that Sweden was a relatively homogeneous nation that could be reduced to a comparatively few types of preference functions. To the extent Wicksell's sociological presumption was accurate, this meant that a system of proportional representation could be developed that would enable a parliament to be selected that would be a miniature representation of Swedish society. If Swedish society were reasonably well represented by, say, seven types of preference functions, it would be plausible to develop a system of proportional representation that had seven parties weighted in parliament similarly to their weights in the society at large. Given this parliamentary arrangement, any proposal for public expenditure would be accompanied by a proposal to finance that expenditure. In light of Wicksell's sociological assumptions, a high degree of support within parliament would plausibly translate 
into high support within Swedish society. One might dispute whether constructing such a scheme of proportional representation would be an easy task. One might also wonder about how a system of rules of parliamentary procedure might be designed for a system of qualified majority voting when extant parliamentary rules are based on majority voting. However such research questions might be resolved, the point to note is that the Wicksellian scheme is not represented adequately by reducing it to a voting rule because that voting rule is embedded within a structure of parliamentary rules.

It was also embedded within presumptions about the character of the executive part of the government. In Sweden, the executive branch was headed by a monarch, though that scheme could also be adapted to an elected executive. Just as feudal princes derived much revenue from management of their estates, so could the executive in Wicksell's scheme. The executive would operate in a position of residual claimacy by creating programs that parliament would support. To obtain parliamentary support, however, is nothing like obtaining legislative support within a two-party system based on majority rule, where Riker's (1962) size principle comes into play under which successful rule inclines toward minimizing the size of the winning coalition. With multiple parties characterized by heterogeneous preferences and with collective action requiring a high degree of consensus, the consensual properties of collective action would approximate the consensual properties of market action. With market action people don't pay for what they don't choose to buy; with collective action within a consensual framework, the instances of people paying for what they oppose would be rare - and with the extent of rareness varying directly with the degree of inclusivity of the required voting rule.

\section{PROPERTY RIGHTS AND SYSTEMS OF GOVERNANCE}

The pure theory of a market economy seeks to explain how orderly societal patterns of economic activity arise through interactions among individuals, no one of whom is acting so as to promote particular societal patterns. Such market processes generate societal patterns that have the appearance of being someone's creation even though they are not because they are generated through interaction within a set of institutions that promote such patterns. Those institutions are primarily alienable property rights and freedom of contract. Property can be privately held without being alienable, as illustrated by primogeniture where landed estates could not be subdivided and so had to pass to eldest sons. When alienable property 
is combined with freedom of contract, a market economy takes shape. Within that form of economic organization, there are strong tendencies for people to deploy their rights of property in ways they value most highly and for people to produce services that other people desire sufficiently to make production worthwhile.

To refer to "tendencies" is to employ plausible reasoning, which is how the classical economists reasoned. Whether the classical scheme of thought is thought to originate with the Spanish Jesuits from Salamanca, the physiocrats from France, or Adam Smith a little later in Great Britain, what arose was a scheme of explanation that was thought to pertain to the preponderance of economic activity which was carried out under private property and freedom of contract. In those days, governments might have accounted for five or ten percent of all economic activity. A theory of market interaction would give a reasonable account of the preponderance of economic activity within society. Collective activity was placed within a type of theoretical black box, as was doubtlessly suitable for the monarchical regimes of the time. Monarchs had their property rights, and with those rights often entailing the ability to impose on subjects. While it would be plausible to describe a monarch as making choices and assimilate a monarch's actions to those of a consumer or a firm, such explanation would be highly idiosyncratic and dependent on autobiographic details pertinent to each monarch. Such explanation stands in stark contrast to the systemic quality of economic reasoning where the analytical emphasis is placed on different systems of relationships and interactions.

In this respect, it is notable that Wicksell sought to embed the Swedish monarch within the market system of Swedish society. It is also notable that Wicksell registered strong objection to how economists treated government in their theories:

... with some very few exceptions, the whole theory [of state activity] still rests on the now outdated political philosophy of absolutism. The theory seems to have retained the assumptions of its infancy, in the seventeenth and eighteenth centuries, when absolute power ruled almost all Europe.... Even the most recent manuals on the science of public finance frequently leave the impression ... of some sort of philosophy of enlightened and benevolent despotism .... (Wicksell 1958: 82)

With the advent of democratic regimes, the distinction between private property and public property blurred. In feudal times the prince had his property rights and subjects had theirs within a system of estates and classes. With the disappearance of feudal relations, princely property rights disappeared, to be replaced by the claims of democratic governments.

This replacement creates a challenge for the conceptualization of 
property rights and the meaning of market economies. Within democratic regimes there are clearly public or political property rights in place. Collective action is impossible without some scheme of political property rights to order relationships among participants within political processes. With feudal regimes, the distinction between rulers and subjects was a fact of birth. With democratic regimes, the distinction is still recognizable but it is an emergent quality of social interaction and not the destiny of birthright. Wagner (2007) argues that both public and private property rights are resident in human nature, even if they manifest themselves differently across institutional regimes. Humans are social creatures, even if not to the extent of the dogs with which we have been associated for so many millennia (Franklin 2009). This sociality provides a bedding ground for public property to grow, though not necessarily in a manner agreeable to everyone. The other side of human nature is a desire for accomplishment and to choose how to live. These two sides of human nature can conflict within an individual as well as conflicting among individuals. Conflict among individuals is easy to grasp, and can be illustrated by conflict among people who appraise differently the communal and individual facets of the structured living together that societies bring in their train.

Conflict within an individual is perhaps more difficult for economists to grasp in light of a long-standing disciplinary convention that everyone necessarily operates with well-ordered utility functions. This convention is a facet of the elevation of demonstrative reasoning that accompanied the ascendancy of the neoclassical style of economic reasoning. Well-ordered utility functions preclude any conflict within an individual, though this preclusion is surely more a feature of a particular scheme of thought than it is a universal feature of human nature. An alternative orientation toward human nature is captured by the ancient concern with the orderliness of the soul, which Isaiah Berlin's (1991) title expresses nicely in its reference to Immanuel Kant's (1784 [1991]) assertion that "out of the crooked timber of humanity no straight thing was ever made." For instance, people surely desire to have a sense of accomplishment and mastery in some sphere of life. This is a rather stoical or ascetic aspect of life. Human nature also contains more hedonistic qualities that can morph into slothfulness and its cousins, perhaps abetted by governmental programs that remove some of the cares and actions that would normally accompany efforts to seek accomplishment. For instance, regulations that restrict competition replace genuine accomplishment with faux accomplishment for the beneficiaries of such regulation.

The pure theory of a market economy is an intellectual construction based on a conceptualization of a system of absolute property rights that is nowhere to be found. One might claim that it pertains to Robinson Crusoe 
alone on his island, but the very concept of property rights is meaningless in that setting. A property right is not a thing but rather is a relationship between or among people. Property rights have meaning only within societies, so a person's rights of property are limited by the willingness of other people to forbear from interfering with any particular person's chosen activity. Where that forbearance ends, public property begins. Once this is recognized, it must also be recognized that dividing lines between state and market are blurry and subject continually to contestation. This is the vision of entangled political economy, which stands in contrast to the customary notion of additive political economy. It is also the vision of Virginia political economy that was present at its founding around 1960, even if that founding appears somewhat differently when viewed from within the swirling intellectual currents that were then active.

\section{TREATING POLITICS AS A PECULIAR TYPE OF BUSINESS PRACTICE}

It is easy to see that politics is a particular type of business activity. Pretty much anything that can be said about practical business activity pertains to practical political activity as well. It is through business activity that most people earn their livelihoods; however, a good number of people earn their livelihoods through political activity, as McCormick and Tollison (1981) note in their effort to treat political economy in explanatory rather than in hortatory fashion. Politics is but one of the many career paths that people can pursue. Business is a competitive activity. So is politics. In democracies, elections are perhaps the most visible example of competition, but elections are not the only site of political competition and might not even be the most significant site. Competition is present throughout the political world just as it is present throughout the commercial world. Within the business world, firms compete with one another. A successful firm this year might be gone from the commercial landscape five years later because other firms were more successful in attracting customers. Within firms, moreover, people compete to advance to superior positions within their current firms while also competing to attain superior positions within other firms. It is the same with politics. Politicians compete to attain elected office, and also compete to secure offices they value more highly than their present offices. People who work within governmental agencies likewise compete among themselves for advancement to more desirable positions. Competition is ubiquitous in social life, regardless of whether the activity in question is ordinarily designated as being political or economic.

Entrepreneurship is a creative human activity that bridges present and 
future. It is through entrepreneurship that old offerings and programs give way to new ones. Entrepreneurship is widely recognized to be significant for commercial practice. Business schools, for instance, often offer courses and some even have programs on entrepreneurship. Political practice likewise exhibits entrepreneurial activity. Whether entrepreneurship is commercial or political, it consists of someone taking a leadership position in trying to insert a new program, product, or service into society. Sometimes those entrepreneurial actions are successful, but often they fail. However particular efforts might fare, they are features of both political and economic practice.

Successful business practice requires the cultivation of supporters of various types. A significant part of that support will come from investors who believe that a particular business might be successful with sufficient capital support. After they have acquired support from investors, businesses will have to attract customers and clients, and will have to keep them despite the ability of those customers and clients to take their business elsewhere. It is the same with political practice. No potential candidate for elected office becomes an actual candidate without acquiring supporters and investors. Linguistic convention refrains from using the term "investor" in connection with the offering of support to candidates and politicians. All the same, the two terms are indistinguishable with respect to the activities to which they point. Someone makes an investment in response to having anticipated that doing so will help to bring about a situation that the investor regards as more desirable than what would otherwise have occurred. Within the commercial world, that greater desirability is customarily expressed in terms of anticipated changes in net worth for the investor. The political world does not generate such a monetary indicator in any direct fashion because political practice is organized within an institutional framework that is incapable of generating prices and transferable claims to ownership rights over cash flows. This institutional difference between political and commercial practice is simply a reflection of the different schemes of ownership that pertain to political and commercial practice. Political practice still generates returns for investors, only it does so in a peculiar manner when compared against commercial practice.

The commercial world is filled with advertising and public relations types of activity in the effort to reach out to customers. So, too, is the political world. Advertising and other public relations activities are prominent within political enterprises just as they are within commercial enterprises. Without doubt, the practice of politics entails a wide variety of activities that are common to both politics and business. Politics, however, is not just one among many instances of the generic practice of business and indistinguishable from the other instances. Politics is rather a peculiar instance 
of business practice, and these peculiar features can ramify throughout the society in which both ordinary and peculiar forms of business activity occur. Among other considerations, there is good reason to think that political enterprises operate in scale-free fashion (Barabási 2002). This scale-free quality means that political entities acquire different operating qualities as their scale of operation expands.

Growing entanglement between the political and the economic can ramify throughout society in the presence of this scale-free quality. The institutions and conventions of private property and free competition operate to give small and large firms pretty much the same properties of being forced systemically to serve consumer desires. The situation can be different with democratic polities, thereby leading large governments to have different properties from small governments. As Jonathan Hughes (1977) explains, governmental involvement in private businesses was present even in Colonial times, but it acquired different qualities as commingling between government and business grew. What Sanford Ikeda (1997) calls the dynamics of intervention undergoes qualitative transformation with increases in the relative number of politically based enterprises in society. To be sure, Patrick and Wagner (2015) explain that intervention is a misleading notion within a framework of entangled political economy. In either case, competition operates differently in limiting the sizes of political and economic enterprises. The peculiar features of the organization of political activity can transform a social system based largely on freedom of enterprise into a cousin of the old systems of feudal relationship where social relations are governed increasingly by principles of status and standing rather than by principles of mutuality and equality.

While successful political practice requires investors, many of those investors are forced investors. A good part of such investment surely occurs under duress, as well as under recognition that such investment can be prudent in light of the ability of political practice to marshal force. Someone might invest in a politician or party because of a simple belief that the politician's program offers a better direction for political organizations within a society than the alternative direction without that investment. Such investments might also be made because it is thought that it will place the investor in the position of acquiring some shield from the undesired taxation or regulation that otherwise might come the investor's way.

Success cannot be gauged the same way in political activity as it is in commercial activity. For commercial activity, success can be gauged by the value of the enterprise. The institutions of private property and freedom of contract operate to generate valuations for all commercial enterprises. In many instances this valuation is generated directly through the operation 
of stock exchanges. Even for closely held businesses, however, valuation is present because those enterprises can still be sold. Political enterprises are not subject to sale, so no valuation can be attached to such enterprises. A privately held school can be sold, so it can be valued and changes in its value through time can be noted and observed. A publicly held school has no valuation as an enterprise, even though some of its assets can be sold.

Political practice bears an unavoidably parasitic relationship to market practice. Political activity cannot generate valuations for political enterprises and their activities. Yet those enterprises must continually engage in economic calculation because all action requires choices among options, and choice requires valuation. Cost and choice are two images of the same reality (Buchanan 1969). The necessity of making choices requires valuation because the cost of choosing one option is the value associated with the option not chosen. With respect to political activity, market prices can provide useful points of orientation for political enterprises. For instance, it is unlikely that political programs will be created around objects that have little market value to directly affected parties. Political enterprises can gain insight into the substantive construction of their programs by using market prices to gauge where political value might lie, even as those programs also operate to change market prices. After all, the very idea of "reform" would be meaningless if it did not lead to some changes in market prices, even if the actual pattern of such changes is beyond direct control as distinct from influence. In other words, political enterprises require some of the information market exchange generates even though those enterprises are also engaged in changing the terms of trade that are generated through market activity.

Any business has products or services for which it seeks customers. The producer-customer relationship is a universal form that fits numerous particular situations. That universal form holds for political enterprises just as it holds for commercial enterprises. The particular actions that occur inside those universal forms differ to a significant degree, and with those differences being conveyed in large measure by Vilfredo Pareto's (1935) distinction between logical and non-logical action. Logical action pertains to what economists describe as inspection or experience goods (Nelson 1970). These are goods for which consumers can discern relevant qualities simply by inspecting them or sampling them. These are the types of goods that commercial enterprises mostly produce. Within the environment of competition among commercial enterprises, vendors must be able to survive in open competition with other vendors when customers can compare their ex post experiences with their ex ante imaginations.

It is different for competition among political enterprises. A good deal of the activities of local governments involves inspection and experience 
goods, as illustrated by municipal playgrounds or golf courses. At higher levels of government, the mix of activity changes with credence goods becoming more common. Credence goods conform to Pareto's notion of non-logical action. For credence goods, it is impossible to test producer claims about the qualitative aspects of the vendor's services, as Emons (1997) examines. In this setting, competition among vendors takes on a significantly ideological character whereby vendors seek to elicit sympathetic responses from potential customers, the results of which can result in people supporting what they would have rejected had they been able to evaluate it directly through inspection or experience (Backhaus 1978). To some degree, political competition revolves around the articulation of images (Boulding 1956) in an environment where those images cannot be subjected directly to some test of their comparative truth values.

\section{NOTES}

1. Simmons (2011) is a lucid textbook presentation of public choice ideas; Mueller (2003) is a professional-level treatise; Shughart and Razzolini (2001) is a wide-ranging collection of essays by notable public choice scholars.

2. In Wagner (2015a) I also associate Virginia political economy with the Austrian tradition of economic theory. Austrian ideas were treated with great respect in Charlottesville in the early 1960s, only those ideas were viewed as an aspect of the classical tradition of liberal political economy and not as a distinctive school of economic theory.

3. The neoclassical emphasis on resource allocation finds its political counterpart in Harold Lasswell's (1936) treatment of politics as centrally concerned with who gets what, when they get it, and how they do that.

4. Harold Berman (1983) is a recent treatise that reflects an orientation similar to Maine's. 